\title{
IMPLEMENTASI PSIKOEDUKASI TOILET TRAINING MELALUI DEMONTRASI VIDEO DAN FLASH CARD TERHADAP PENINGKATAN PENGETAHUAN IBU DAN KEMAMPUAN TOILET TRAINING ANAK TODDLER DI SEKOLAH TODDLER HARAPAN BUNDA
}

\author{
Machmudah \\ FKIP, Universitas Nahdlatul Ulama Surabaya \\ Email: machmudahsyarifsubagyo@gmail.com
}

\begin{abstract}
Abstrak. Pada usia toddler harus dilatih toilet training. Salah satu upayanya memberikan psikoedukasi dengan metode demonstrasi video dan flash card kepada ibu kemudian dilanjutkan pada anak. Tujuan penelitian untuk mengetahui pengaruh psikoedukasi dengan demonstrasi video dan flash card terhadap peningkatan pengetahuan ibu dan kemampuan toilet training pada anak. Metode penelitian quasi eksperimental dengan rancangan pre and post test control group design non randomized. Populasi penelitian adalah ibu yang mempunyai anak usia toddler di sekolah toddler "Harapan Bunda" Surabaya, menggunakan total sampling berjumlah 30 responden. Analisis datanya Mann Whitney U Test \& Wilcoxon Rank Test dengan tingkat signifikansi 5\% $(\alpha=0,05)$.

Hasil penelitian menunjukkan setelah diberi psikoedukasi pada kelompok perlakuan mempunyai rerata 46,27 menigkat menjadi 78,07 hal ini menunjukkkan bahwa pengetahuan ibu meningkat setelah di beri psikoedukasi. Selain itu hasil rerata $=78,07$ (post) pada kelompok perlakuan lebih tinggi daripada kelompok kontrol $(53,40)$ dengan nilai signifikan $\mathrm{p}=0,000$ yang berarti pengetahuan ibu pada kelompok perlakuan benar-benar berbeda dengan kelompok kontrol. Sedangkan pada kemampuan toileting anak hasil rerata yang semula 11,33 menigkat menjadi 14,80 menunjukkan bahwa kemampuan anak melaksanakan toilet training meningkat setelah di berikan psikoedukasi, selain itu hasil rerata $=14,80$ (post) pada kelompok perlakuan lebih tinggi daripada rerata pada kelompok kontrol $(11,80)$, dengan nilai signifikan $\mathrm{p}=0,00$ berarti kemampuan anak pada kelompok perlakuan benar-benar berbeda dengan kelompok kontrol. Kesimpulan penelitian ini menunjukkan bahwa pemberian psikoedukasi dengan metode demonstrasi video dan flash card berpengaruh terhadap peningkatan pengetahuan ibu dan kemampuan toilet training anak toddler di sekolah toddler "Harapan Bunda" Surabaya. Dengan demikian 3 hipotesis yang diajukan dalam peneltian ini diterima.
\end{abstract}

Kata Kunci: Psikoedukasi, video, flash card, toilet training, toddler

Abstract. The purpose of this research is to determine whether Psychoeducation with media video and flash card can increase mother knowledge and Toilet Training ability for toddler . It is a quantitative research. This research is Queasy Experiment with pre and post test control group design non randomized.. The population was devided into two group, experimental group and control group. It was all toddlers in informal school play group. The total sample is 30 toddlers. It was divided into two groups using purposive totally sampling technique. The data collection technique was : 1. Mother Knowledge Scale; 2. Observation sheet about toilet training ability; and 3. Elimination toddler schedule in 24 hours. The analyzed of date using Mann Whitney U Test \& Wilcoxon Rank Test with a signifikansi 5\% $(\alpha=0,05)$. The finding research showed that there was influence and Psychoeducation with demontration media video and flash card toward increasing mother knowledge and toilet training ability for toddler. There was significant improvement (influence) in $p$ value $=0.001$ ( $p$ value $<0.05$ ). this result gave recomendation for play group and parents to give modeling media video and flash card about toilet training to increase mother knowledge and ability toilet training toddler.

Keyword : Psychoeducation, video, flash card, toilet training, toddler 


\section{PENDAHULUAN}

Lima tahun pertama kehidupan anak merupakan awal bagi proses tumbuh kembang anak, baik fisik maupun psikisnya. Anak-anak yang dapat menyelesaikan tugas tumbuh kembangnya pada tahap ini akan mengalami keterlambatan pada tahap tumbuh kembang berikutnya (Wong, 2008).

Usia toddler (1-3 tahun) merupakan usia emas karena anak di usia ini mengalami pertumbuhan dan perkembangan yang sangat cepat.Perkembangan psikologis pada usia toddler merupakan perubahan dari fase percaya $v s$ tidak percaya menjadi fase otonomi $v s$ ragu-ragu malu yang ditunjukkan dengan sikap kemandirian yang semakin meluas. Pada masa ini anak dapat mengontrol bagian tubuhnya,kemampuan dalam berbahasa meningkat, dan pada fase ini juga berada pada fase anal dimana anak mulai mampu untuk mengontrol buang air kecil (BAK) dan buang air besar (BAB) (Luxner, 2005).

Salah satu tugas perkembangan masa toddler adalah toilet training. Toilet training pada anak merupakan suatu usaha untuk melatih agar anak mampu mengontrol dalam melakukan buang air kecil dan buang air besar. Tindakan untuk latihan buang air kecil dan besar pada anak membutuhkan persiapan baik secara fisik, psikologis maupun secara intelektual, melalui persiapan tersebut, diharapkan anak mampu mengontrol buang air besar atau kecil secara sendiri (Hidayat, 2009). Toilet training membutuhkan faktor psikofisiologis kompleks untuk kesiapan. Anak harus mampu mengenali urgensi untuk mengeluarkan dan menahan eliminasi serta mampu mengomunikasikan sensasi ini kepada orang tua, selain itu mungkin ada berbagai motivasi yang penting untuk memuaskan orang tua dengan menahan, daripada memuaskan diri dengan mengeluarkan eliminasi (Wong, 2008).

Salah satu stimulasi penting dilakukan orang tua adalah stimulasi terhadap kemandirian anak dalam melakukan BAB dan BAK. Kebiasaan mengompol pada anak usia di bawah 2 tahun masih dianggap sebagai hal yang wajar. Anak mengompol di bawah 2 tahun disebabkan karena anak belum mampu mengontrol kandung kemih secara sempurna. Kebiasaan mengompol umumnya masih terbawa sampai usia 4-5 tahun. Kasus yang ditemukan di Indonesia anak usia 6 tahun yang masih mengompol sekitar 12\% (Asti, 2008). Menurut penelitian American Psychiatric Association, dilaporkan bahwa 10-20\% anak usia 5 tahun, 5\% anak usia 10 tahun, hampir 2\% anak usia 12-14 tahun, dan $1 \%$ anak usia 18 tahun masih mengompol (noctural enuresis), dan jumlah anak laki-laki 
yang mengompol lebih banyak dibandingkan anak perempuan.

Pada toilet training selain melatih anak dalam mengontrol buang air besar dan kecil juga dapat bermanfaat dalam pendidikan seks sebab saat anak melakukan kegiatan tersebut disitu anak mempelajari anatomi tubuhnya sendiri serta fungsinya. Proses toilet training diharapkan terjadi pengaturan impuls atau rangsangan dan instink anak dalam melakukan buang air besar atau buang air kecil dan perlu diketahui bahwa buang air besar merupakan suatu alat pemuasan untuk melepaskan ketegangan, dengan latihan ini anak diharapkan dapat buang air besar atau kecil secara sendiri (Hidayat, 2009).

Toilet training membutuhkan faktor psikofisiologis kompleks untuk kesiapan. Anak harus mampu mengenali urgensi untuk mengeluarkan dan menahan eliminasi serta mampu mengomunikasikan sensasi ini kepada orang tua, selain itu mungkin ada berbagai motivasi yang penting untuk memuaskan orang tua dengan menahan, daripada memuaskan diri dengan mengeluarkan eliminasi (Wong, 2008).

Menurut teori Sigmund Freud pada fase ini sudah waktunya anak dilatih untuk buang air atau toilet training (pelatihan buang air pada tempatnya). Anak juga dapat menunjukkan beberapa bagian tubuhnya menyusun dua kata danmengulang kata-kata baru. Anak usia toddler (1-3 tahun) yang berada pada fase anal yang ditandai dengan berkembangnya kepuasan (kateksis) dan ketidakpuasan (antikateksis) di sekitar fungsi eliminasi (Luxner, 2005).

Berdasarkan pengamatan dan wawancara peneliti, dengan ibu-ibu di Tempat Penitipan Anak dan Kelompok Bermain yang ada di wilayah Ketintang Surabaya dengan mewawancarai 10 orang ibu yang memiliki anak usia 2-3 tahun untuk mengidentifikasi permasalahan toilet training pada anak usia toddler, diketahui bahwa sebanyak 7 orang ibu yang memiliki anak usia 2-3 tahun menyatakan untuk memilih menggunakan diapers dengan alasan karena lebih praktis dan tidak ada waktu yang cukup untuk anaknya karena bekerja, 1 orang ibu yang memiliki anak berusia 29 bulan mengatakan bahwa anaknya memiliki masalah pada saat mau BAB sehingga mengharuskan untuk menggunakan diapers, dan sebanyak 2 orang ibu yang memiliki anak usia 2-3 tahun menyatakan anaknya sudah berhasil dalam menerapkan toilet training dan sudah bisa memberitahu orang sekitar jika ingin BAK dan BAB, salah satu ibu mengakui bahwa anaknya melihat contoh dari kakaknya yang sudah bisa BAK dan BAB ke toilet. Peneliti juga mewawancarai ibu-ibu di Kelompok Bermain Anak yang berbeda, ditemukan 5 anak dengan rentang usia 30-36 
bulan, 3 orang Ibu mengatakan sudah melatih anaknya agar memberitahu ibunya jika ingin buang air kecil, 1 orang ibu mengatakan setiap bangun tidur selalu membawa anaknya ke kamar mandi, dan 1 orang ibu mengatakan anak laki-lakinya selalu diajarkan oleh suaminya cara buang air kecil ke kamar mandi.

Peneliti juga mewawancarai Ibu-ibu lain di Tempat Penitipan Anak Ketintang Surabaya, seorang Ibu mengatakan bahwa telah mengajarkan anaknya toilet training dengan memberitahu Ibu jika ingin pipis, tetapi sering gagal karena anaknya selalu memberitahu ibu setelah selesai pipis, apalagi jika pipisnya di karpet dan di sofa, kadang ibu tidak sengaja memarahi anaknya. Berbeda dengan Ibu lain, dengan cara yang sama memberi tahu Ibu jika ingin pipis terlebih dahulu, membuat anaknya sering menahan pipisnya, karena Ibu mengaku anaknya selalu takut dan menangis jika dibawa pipis ke toilet. Salah seorang Ibu lagi mengatakan bahwa anaknya jika di rumah sudah bisa pipis ke toilet, tetapi jika sudah dititipkan di Tempat Penitipan Anak, anaknya selalu pipis di celana dan akhirnya harus menggunakan diapers.

Usaha untuk melatih anak dalam buang air kecil dan buang air besar dapat dilakukan dengan cara memberikan contoh dan anak menirukannya secara benar, mengobservasi saat memberikan contoh toilet training, memberikan pujian saat anak berhasil dan tidak memarahi saat anak gagal dalam melakukan toilet training (Gupte,2004). Bandura menyebutkan bahwa belajar melalui observasi dapat terjadi hanya dengan menonton modelnya saja dan melalui observasi tersebut seorang anak dapat belajar berprilaku. Anak kemungkinan tidak langsung memberikan respon (perilaku) yang langsung dapat diobservasi, tetapi anak menyimpan apa yang diobservasinya tersebut dalam bentuk kognitifnya (cognitive form). Bentuk kognitif ini tetap aktif dalam diri anak dan pada saat anak berada pada situasi atau kondisi yang serupa, secara spontan cognitive form tadi turut serta menentukan perilaku si anak dalam kondisi tersebut. Perilaku model yang telah diobservasi anak melalui tayangan TV, film video, gambar, dan video game dapat menjadi bahan cognitive form si anak.

Model perilaku cognitive form tersebut menjadi bahan referensi bawah sadar, yang apabila anak bertemu dengan situasi yang serupa kelak akan memberikan respons seperti dia telah melihat bagaimana modelnya memberi respons (Alwisol, 2004).

Penelitian yang dilakukan Keen dan Cruskelly (2007) dalam Toilet training for children with autism: the effects of video modeling menunjukkan bahwa model video dapat meningkatkan pencapaian BAK 
siang hari di kalangan anak-anak autisme. menitipkan anaknya di Tempat Penitipan Frekuensi BAK di toilet lebih besar bagi Anak di Surabaya, masih banyak anak-anak autis yang menonton video toilet didapatkan permasalahan toilet training training dibandingkan anak-anak yang tidak yang dihadapi orang tua. Misalnya saja menonton.Penelitian tersebut juga dengan kesibukan orang tua, sehingga menyebutkan anak autis yang diberi orang tua tidak mempunyai waktu untuk petunjuk kartu bergambar tentang mengajarkan anak tentang toilet training. pengarahan untuk ke toilet, mengalami Umumnya anak-anak yang dititipkan di peningkatan frekuensi BAK di toilet. Tempat Penitipan Anak dan Kelompok Penelitian yang dilakukan Salimah Bermain dengan rentang usia 18-36 bulan (2011) dengan judul dampak penerapan masih menggunakan diapers.

bermain dengan media gambar seri dalam mengembangkan keterampilan berbicara dan penguasaan kosakata anak usia dini berpengaruh terhadap keterampilan berbicara dan penguasaan kosakata anak dibandingkan dengan bermain tanpa menggunakan media gambar seri, hal ini diindikasikan dalam peningkatan jumlah kosa kata yang dipergunakan dalam berbicara. Berdasarkan fenomena di atas peneliti tertarik untuk mengetahui apakah ada "Implementaasi psikoedukasi toilet training melalui video dan flash card terhadap pengetahuan ibu dan kemampuan toilet training pada anak toddler."

Muscari (2005) menyatakan bahwa seharusnya anak usia 18-24 bulan atau masa usia pra sekolah hendaknya telah mendapatkan pelaksanaan toilet training oleh orang tuanya, tapi kenyataanya yang peneliti dapat di Psikoedukasi toilet training melalui video lingkungan sakitar peneliti dan dari dan flash card terhadap peningkatan wawancara dengan beberapa ibu-ibu yang pengetahuan ibu dan kemampuan toilet 
training pada anak toddler?

Tujuan penelitian ini adalah

untuk membandingkan pengetahuan ibu dan kemampuan toilet training pada anak toddler sebelum dan sesudah diberi intervensi psikoedukasi toilet training melalui demonstrasi video dan kartu bergambar dan untuk membandingkan pengetahuan ibu dan kemampuan toilet training anak toddler pada kelompok yang diberi intervensi dan pada kelompok yang tidak diberikan intervensi.

\section{METODE}

Desain penelitian yang digunakan adalah Quasy Experiment Design bentuk PrePost Test Non Randomized Control Group Design.penelitian ini melibatkan dua kelompok, yaitu kelompok eksperimen dan kelompok kontrol. Dalam penelitian ini kelompok eksperimen diberi intervensi atau perlakuan, sedangkan pada kelompok kontrol tidak diberi intervensi. Pada kelompok eksperimen dan kelompok kontrol masing-masing dilakukan pengukuran sebelum diberikan intervensi (pre-test) dan setelah diberikan intervensi (post-test) (Hidayat, 2007). Penelitian ini menggunakan purposive sampling (judgment sampling) yaitu suatu teknik penetapan sampel dengan cara memilih sampel diantara populasi sesuai dengan yang dikehendaki peneliti (Nursalam, 2009).

Jumlah sampel dalam penelitian ini adalah sebesar populasi yaitu sebanyak 30 orang, yang semuanya masuk dalam kelas/kelompok A1 dan A2. Kemudian jumlah sampel tersebut dibagi menjadi 2 kelompok masing-masing 15 orang. Kelompok A1 diberikan intervensi sehingga disebut sebagai kelompok perlakuan, Kemudian kelompaok berikutnya disebut sebagai kelompok control. Pembagian kelompok didasarkan pada procedure matching (menjodohkan), dengan cara membagi dalam dua kelompok yang sama, menyetarakan jumlah sampel antara kelompok perlakuan dan kelompok kontrol.

Adapun alat pengumpul data dalam penelitian ini berupa :

1. Skala Pengukuran Pengetahuan Ibu

2. Lembar Checklist Observasi Kemampuan Toilet training Anak

3. Lembar Jadwal Eliminasi (BAK dan BAB) selama 24 jam.

Analisis datanya menggunakan uji statistik Wilcoxon Signed Rank Test (uji komparasi 2 sampel berpasangan) dan Mann Whitney $U$ dengan tingkat kemaknaan $\mathrm{p}<$ 0,05

\section{HASIL DAN PEMBAHASAN}

1. Pengetahuan Ibu dan Kemampuan Anak sebelum Diberikan Psikoedukasi Toilet Training pada Kelompok Perlakuan dan Kelompok Kontrol 


\begin{tabular}{|l|l|l|l|l|l|}
\hline $\begin{array}{l}\text { Komponen } \\
\text { Variabel }\end{array}$ & Mean & $S D$ & $Z$ & $\begin{array}{l}P \text { (2- } \\
\text { tailed) }\end{array}$ & Makna \\
\hline $\begin{array}{l}\text { Pengetahuan } \\
\text { Ibu(Y1) }\end{array}$ & 49,10 & 7,984 & - & 0,067 & $\begin{array}{l}>0,05 \\
\text { T'ada } \\
\text { beda }\end{array}$ \\
\hline $\begin{array}{l}\text { Kemampuan } \\
\text { Anak (Y2) }\end{array}$ & 11,40 & 1,102 & $\begin{array}{l}-0, \\
215\end{array}$ & 0,829 & $\begin{array}{l}>0,05 \\
\text { T'ada } \\
\text { beda }\end{array}$ \\
\hline
\end{tabular}

Tabel 2. Perbandingan pengetahuan ibu sebelum dan sesudah pemberian psikoedukasi pada kelompok perlakuan dan kelompok kontrol.

Tabel 1. Pengetahuan ibu dan Kemampuan anak melakukan Toilet Training sebelum diberikan Psikoedukasi tentang Toilet Training pada kelompok Perlakuan dan kelompok Kontrol

Hasil analisis Tabel 1. didapatkan bahwa berdasarkan uji Mann Whitney diperoleh nilai $\mathrm{z}=-1,829$ dengan nilai $\mathrm{p}=$ 0,067, dimana $\mathrm{p}>0,05$ yang artinya tidak ada perbedaan nilai pengetahuan ibu sebelum diberikan Psikoedukasi tentang Toilet training antara kelompok perlakukan dan kelompok kontrol.

Kemampuan anak dalam melakukan toilet training, berdasrkan uji Mann Whitney diperoleh nilai $\mathrm{z}=-0,215$ dengan nilai $\mathrm{p}=$ 0,829 dimana $p>0,05$ yang artinya tidak ada perbedaan yang signifikan antara kemampuan anak pada kelompok perlakuan dan kelompok control dalam melakukan toilet training sebelum diberikan psikoedukasi.

2. Pengaruh pemberian Psikoedukasi tentang Toilet Training dengan Demonstrasi melalui Video dan Kartu Bergambar terhadap Pengetahuan Ibu

\begin{tabular}{|l|l|l|l|l|l|l|}
\hline & \multicolumn{2}{|l|}{ Perlakuan } & \multicolumn{2}{l|}{ Control } & $\begin{array}{l}\text { Perlak } \\
\text { uan }\end{array}$ & $\begin{array}{l}\text { Contro } \\
\text { l }\end{array}$ \\
\cline { 2 - 7 } & Pre & Post & Pre & Post & Post & Post \\
\hline Mean & 46,27 & 78,07 & 51,93 & 53,40 & 78,07 & 53,40 \\
\hline SD & 7,478 & 2,712 & 7,675 & 8,007 & 2,712 & 8,007 \\
\hline & $\begin{array}{l}\mathrm{p}=0,001 \\
\mathrm{z}=-3,410 \\
\text { Wilcoxon Signed } \\
\text { Rank Test }\end{array}$ & $\begin{array}{l}\mathrm{p}=0,011 \\
\mathrm{z}=-2,555 \\
\text { Wilcoxon Signed } \\
\text { Rank Test }\end{array}$ & $\begin{array}{l}\mathrm{p}=0,000 \\
\mathrm{z}=-4,681 \\
\text { Mann-Whitney } \\
\text { Test }\end{array}$ \\
\hline
\end{tabular}

Berdasarkan Tabel 2. di atas perbandingan pengetahuan ibu sebelum dan sesudah pemberian intervensi berupa psikoedukasi toilet training dengan demonstrasi melalui video dan kartu bergambar terjadi peningkatan pengetahuan ibu tentang toilet training. Hal ini dapat di lihat dari uji Wilcoxon Signed Rank Test dengan nilai signifikan $\mathrm{p}=0,001$ dimana $\mathrm{p}<$ 0,05 yang artinya ada perbedaan signifikan setelah diberikan psikoedukasi, yang berarti Ho ditolak. Dengan demikian ada pengaruh pemberian psikoedukasi dengan demonstrasi melalui video dan kartu bergambar terhadap peningkatan pengetahuan ibu.

Hasil rerata yang semula 46,27 (pre) menigkat menjadi $78,07 \quad$ (post) menunjukkkan secara kuantitatif bahwa pengetahuan ibu meningkat setelah di berikan intervensi. Uji statistic dengan Mann-Whitney $U$ Test menunjukkan bahwa nilai signifikan $(p)=0,000$ yang berarti pengetahuan ibu yang mendapat psikoedukasi melalui demontrasi video dan kartu bergambar benarbenar berbeda dengan kelompok kontrol yang tidak mendapat psikoedukasi, walaupun 
secara kuantitatif ada perubahan (pada kolom yang tengah dari rerata 51,93 menjadi 53,40), namun perubahan itu sangat sedikit/tidak berarti. Selain itu hasil rerata $=$ 78,07 (post) pada kelompok perlakuan lebih tinggi daripada kelompok kontrol $(53,40)$ menunjukkan secara kuantitatif adanya peningkatan pengetahuan ibu.pada kelompok perlakuan.

\section{Pengaruh pemberian Psikoedukasi} tentang Toilet Training dengan Demonstrasi melalui Video dan Kartu Bergambar terhadap Kemampuan Anak Melaksanakan Toilet Training

Tabel 3 : Perbandingan kemampuan anak sebelum dan sesudah pemberian psikoedukasi pada kelompok perlakuan dan kelompok kontrol.

\begin{tabular}{|l|l|l|l|l|l|l|}
\hline & \multicolumn{2}{|l|}{ Perlakuan } & \multicolumn{2}{l|}{ Kontrol } & $\begin{array}{l}\text { Perlak } \\
\text { uan }\end{array}$ & $\begin{array}{l}\text { Kontro } \\
\text { l }\end{array}$ \\
\cline { 2 - 7 } & Pre & Post & Pre & Post & Post & Post \\
\hline Mean & 11,33 & 14,80 & 11,47 & 11,80 & 14,80 & 11,80 \\
\hline SD & 1,234 & 0,941 & 0,990 & 1,014 & 0,941 & 1,014 \\
\hline & $\begin{array}{l}\mathrm{p}=0,001 \\
\mathrm{z}=-3,430 \\
\text { Wilcoxon Signed } \\
\text { Rank Test }\end{array}$ & $\begin{array}{l}\mathrm{p}=0,25 \\
\mathrm{z}=-2,236 \\
\text { Wilcoxon Signed } \\
\text { Rank Test }\end{array}$ & $\begin{array}{l}\mathrm{p}=0,000 \\
\mathrm{z}=-4,543 \\
\text { Mann-Whitney } U \\
\text { Test }\end{array}$ \\
\hline
\end{tabular}

Berdasarkan tabel 3 di atas perbandingan kemampuan anak sebelum dan sesudah pemberian intervensi berupa psikoedukasi toilet training dengan demonstrasi melalui video dan kartu bergambar terjadi peningkatan kemampuan anak dalam melaksanakan toilet training. Hal ini dapat di lihat dari uji Wilcoxon Signed Rank Test dengan nilai signifikan $\mathrm{p}=0,001$ dimana $\mathrm{p}<0,05$ yang artinya ada perbedaan signifikan setelah diberikan psikoedukasi, yang berarti Ho ditolak. Dengan demikian ada pengaruh pemberian psikoedukasi dengan demonstrasi melalui video dan kartu bergambar terhadap peningkatan kemampuan anak dalam melaksanakan toilet training.

Hasil rerata yang semula 11,33 (pre) menigkat menjadi $14,80 \quad$ (post) menunjukkkan secara kuantitatif bahwa kemampuan anak melaksanakan toilet training meningkat setelah di berikan intervensi. Uji statistic dengan Mann-Whitney $U$ Test menunjukkan bahwa nilai signifikan $\mathrm{p}$ $=0,000$ yang berarti kemampuan anak yang mendapat psikoedukasi melalui demontrasi video dan kartu bergambar benar-benar berbeda dengan kelompok kontrol yang tidak mendapat psikoedukasi, walaupun secara kuantitatif ada perubahan (pada kolom yang tengah dari rerata 11,47 menjadi 11,80 ), namun perubahan itu sangat sedikit/tidak berarti. Selain itu hasil rerata $=14,80$ (post) pada kelompok perlakuan lebih tinggi daripada rerata pada kelompok control $(11,80)$, hal ini menunjukkan secara kuantitatif adanya peningkatan kemampuan anak dalam. melaksanakan toilet training pada kelompok perlakuan.

4. Pengaruh Pemberian Psikoedukasi Toilet Training dengan Demonstrasi melalui Video dan Kartu bergambar terhadap Pengetahuan Ibu dan Kemampuan Anak 
dalam Melaksanakan Toilet training pada Anak Toddler

Tabel 4 : Perbandingan sebelum dan sesudah pemberian psikoedukasi, baik pada pengetahuan ibu maupun pada kemampuan anak dalam melaksanakan toilet training

\begin{tabular}{|c|c|c|c|c|c|c|}
\hline \multirow{3}{*}{\begin{tabular}{|l} 
tervensi \\
Sebelum
\end{tabular}} & Kelompok & & ariabel & & \multicolumn{2}{|r|}{ Iakna } \\
\hline & \multirow[t]{2}{*}{$\begin{array}{l}\text { perlakuan } \\
\text { kontrol }\end{array}$} & \multirow[t]{2}{*}{$\&$} & engetahuan Ibu &, 829 & 067 & $\begin{array}{ll}0,05 & \text { T'ada } \\
\text { eda } & \end{array}$ \\
\hline & & & $\begin{array}{l}\text { emampuan } \\
\text { nak }\end{array}$ & p, 215 & 829 & $\begin{array}{ll}\text { 0,05 } & \text { T'ada } \\
\text { eda } & \\
\end{array}$ \\
\hline \multirow[t]{4}{*}{ Sesudah } & \multirow{2}{*}{\multicolumn{2}{|c|}{ perlakuan }} & engetahuan Ibu & $\$, 410$ &, 001 & $\mathrm{eda}^{0,05}$ Ada \\
\hline & & & $\begin{array}{l}\text { emampuan } \\
\text { nak }\end{array}$ & $\$, 430$ & 001 & ${ }_{\mathrm{eda}} 0,05$ Ada \\
\hline & \multirow{2}{*}{\multicolumn{2}{|c|}{$\begin{array}{l}\text { perlakuan } \\
\text { kontrol }\end{array}$}} & engetahuan Ibu &, 681 & 000 & $\mathrm{eda}^{0,05}$ Ada \\
\hline & & & $\begin{array}{l}\text { emampuan } \\
\text { nak }\end{array}$ &, 543 & 000 & $\begin{array}{ll}0,05 & \text { Ada } \\
\text { eda } & \end{array}$ \\
\hline
\end{tabular}

Berdasarkan tabel 4 berdasarkan uji MannWhitney U Test menunjukkan bahwa nilai signifikansi $\mathrm{p}=0,000$ baik pada variable pengetahuan ibu dan kemampuan anak pada sesudah diberi psikoedukasi, dimana $\mathrm{p}<$ 0,005, artinya baik pada pengetahuan ibu maupun pada kemampuan anak yang mendapat psikoedukasi melalui demontrasi video dan kartu bergambar benar-benar ada perbedaan yang signifikan dengan kelompok kontrol yang tidak mendapatkan psikoedukasi, sehingga Ho ditolak. Dengan demikian dapat disimpulkan bahwa : ada pengaruh pemberian psikoedukasi tentang toilet training terhadap pengetahuan ibu dan kemampuan anak toddler dalam melaksanakan toilet training.

Dari hasil penelitian dan analisis data menunjukkan bahwa:

\section{Pengetahuan Ibu tentang Toilet}

\section{Training}

Analisis data pada Tabel 2 menunjukkan bahwa perbandingan pengetahuan ibu sebelum dan sesudah pemberian intervensi berupa psikoedukasi toilet training dengan demonstrasi melalui video dan kartu bergambar terjadi peningkatan pengetahuan ibu tentang toilet training. Hal ini dapat di lihat dari uji Wilcoxon Signed Rank Test dengan nilai signifikan $\mathrm{p}=0,001$ dimana $\mathrm{p}<0,05$ yang artinya ada perbedaan signifikan setelah diberikan psikoedukasi, dengan demikian ada pengaruh pemberian psikoedukasi dengan demonstrasi melalui video dan kartu bergambar terhadap pengetahuan ibu. Hasil rerata yang semula 46,27 (pre) menigkat menjadi 78,07 (post) menunjukkkan secara kuantitatif bahwa pengetahuan ibu meningkat setelah di berikan intervensi. Hal ini di pengaruhi oleh :

a. Adanya pemberian suatu informasi dari luar melalui suatu proses pembelajaran/psikoedukasi dengan menggunakan metode demonstrasi melalui video dan kartu bergambar juga memberikan leaflet. Psikoedukasi ini di berikan secara klasikal dan individual, sebagai evaluasi terhadap keberhasilan pemberian materi psikoedukasi dengan ceramah dan tanya jawab peneliti juga melakukan demonstrasi ulang oleh responden. Demonstrasi ulang ini 
dilakukan dengan harapan agar $\mathrm{ibu/responden} \mathrm{tidak} \mathrm{sekedar} \mathrm{mengetahui}$ dan memahami materi toilet training, tapi juga mampu mempraktikkan secara lisan, sebagai model bagi putra-putrinya selama di rumah, bahkan mampu mempraktikkan menggunakan alat bantu jika memerlukan.

Tingkat pendidikan ibu, harapannya semakin tinggi tingkat pendidikan ibu maka semakin mudah dalam menguasai materi, namun dalam penelitian ini sebagian besar pendidikan terakhir ibu/responden adalah SMP (47\%) dan SMA (40\%) dan hanya $13 \%$ yang mempunyai pendidikan terakhir akademi/perguruan tinggi. Oleh karena itu pemberian intervensi dalam penelitian ini dibuat semenarik mungkin tidak sekedar cermah, tanya jawab dan pembagian leaflet saja, tapi juga disertai dengan metode-meode penunjang lainnya seperti video, kartu bergambar, sehingga diharapkan materi psikoedukasi ini bisa dipahami dan diserap secara optimal (Notoatmodjo, 2007). Pendidikan dasar setingkat SMP yang menurut Notoadmojo (2007) merupakan pendidikan menengah tidak selalu membuat seseorang tidak dapat menangkap materi secara optimal tetapi dengan menggunakan strategi atau metode pembelajaran tertentu, dalam hal ini menggunakan pembelajaran metode demonstrasi maka materi dapat di tangkap secara opimal. Hal ini sesuai dengan yang di kemukakan Muchtar (2005) bahwa pembelajaran metode dem onstrasi dapat di pakai untuk mencapai tujuan psikomotorik untuk tingkat pendidikan dasar dan menengah.

b. Memori, minat dan perhatian juga turut berpengaruh terhadap peningkatan pengetahuan (Nursalam, 2005), seperti halnya minat/antusias responden terhadap materi toilet training. Semula ibu-ibu/responden menganggap remeh manfaat toilet training, tapi setelah mengetahui dampak positif dan negatifnya, mereka menjadi antusias untuk melanjutkan program toilet training ini, sehingga tugas-tugas perkembangan putra-putrinya dapat diselesaikan dengan tuntas. Banyak diantara mereka yang tidak menyangka bahwa tahapan ketrampilan toilet training sedemikian lengkapnya. Psikoedukasi ini memberikan kesempatan pada orang tua anak toddler agar lebih memahami tentang tugas perkembangan yang harus di capai pada anak toddler dalam hal ini adalah toilet training, sehingga orang tua dapat secara dini mengidentifikasi kesiapan anak dalam toilet training dan mendapatkan solusi terhadap masalah yang mungkin timbul akibat toilet training pada anak toddler. 
Yang perlu diperhatikan selama kemampuan anak melaksanakan toilet proses intervensi ini adalah prosedur/tahapan training meningkat setelah di berikan praktik toilet training pada anak toddler yang intervensi. Uji statistik dengan Mannbenar merupakan bagian terpenting dalam Whitney U Test menunjukkan bahwa nilai pembelajaran, hal ini di maksdukan untuk signifikan $\mathrm{p}=0,000$ yang berarti kemampuan menghindarkan pengalaman yang kurang nyaman baik bagi orang tua maupun bagi anak yang efeknya dapat terjadi di masa mendatang. Praktik yang benar pada saat toilet toddler pada anak toddler akan mengurangi kekhawatiran orang tua sehingga anak mendapatkan kemampuan toilet training sesuai dengan tugas perkembangannya.

\section{Kemampuan Toilet Training Pada} Anak Toddler

Berdasarkan Tabel 3 di atas perbandingan kemampuan anak sebelum dan sesudah pemberian intervensi berupa psikoedukasi toilet training dengan demonstrasi melalui video dan kartu bergambar terjadi peningkatan kemampuan anak dalam melaksanakan toilet training. Hal ini dapat di lihat dari uji Wilcoxon Signed Rank Test dengan nilai signifikan $\mathrm{p}=0,001$ dimana $\mathrm{p}<0,05$ yang artinya ada perbedaan signifikan setelah diberikan psikoedukasi, dengan demikian ada pengaruh pemberian psikoedukasi dengan demonstrasi melalui video dan kartu bergambar terhadap peningkatan kemampuan anak dalam melaksanakan toilet training.

Hasil rerata yang semula 11,33 (pre) menigkat menjadi $14,80 \quad$ (post) menunjukkkan secara kuantitatif bahwa anak yang mendapat psikoedukasi melalui demontrasi video dan kartu bergambar benarbenar berbeda dengan kelompok kontrol yang tidak mendapat psikoedukasi. Hal ini di pengaruhi beberapa factor antara lain:

a. Jenis kelamin anak, dimana sebagian besar jenis kelamin anak/responden adalah perempuan (67\%),

Hasil penelitian sebelumnya menegaskan bahwa anak laki-laki memang memulai dan menguasai toilet training lebih lama di banding anak perempuan. Perbedaan ini mungkin di sebabkan oleh beberapa faktor yaitu (Gilbert, dalam Eka, 2008):

1) sistem saraf anak laki-laki berkembang lebih lama

2) anak laki-laki kurang sensitive dengan rasa basah di kulit mereka

3) Anak perempuan kemungkinan mendapatkan kemampuan toilet training lebih awal di sebabkan mereka dapat menyatakan keinginannya dengan kata-kata, hal ini merupakan sebuah mekanisme adaptasi dalam pembatasan diri. Hal ini juga membuat anak perempuan lebih mudah beradaptasi secara emosional dengan orang tuanya 
sehingga respon dalam melakukan toilet training anak lebih baik. Selain itu, mungkin pertimbangan yang lain adalah kematangan neurological anak lelaki membatasi seberapa cepat mereka dapat memperoleh control kandung kemih.

4) Pelatih utama toilet training di lakukan oleh ibu (seorang wanita). Hal ini dapat menjadikan pengalaman yang rumit bagi anak laki-laki. Sesuai dengan teori perkembangan psikososial dari Erikson, anak akan meniru perilaku orang lain di sekitarnya untuk mengembangkan fungsi otonominya dalam mengontrol tubuh dan lingkungan melalui proses belajar. Hal ini yang membuat anak usia toddler lebih cenderung memiliki sifat imitasi, sehingga ia perlu figure yang benar-benar sesuai untuk melatihnya. Padahal, toilet training antara laki-laki dan perempuan berbeda dalam segi cara BAK/BAB dan cara hygiene yang tepat.

5) Anak yang terpilih sesuai dengan kriteria inklusi yaitu anak toddler yang tidak memiliki cacat mental dan fisik, sehingga dapat mempermudah pengidentifikasian kesiapan anak.

6) Kemampuan anak secara optimal akan di dapatkan apabila terdapat interaksi yang positif antara orang tua terutama ibu dan anak. Sebagaimana disampaikan oleh Stanley dalam Hardy (2011) bahwa memaksakan anak untuk mendapatkan kemampuan toilet training sejak dini akan terlebih dahulu di identifikasi kesiapannya.

7) Hardy (2011) menjelaskan bahwa anak-anak yang didampingi oleh orang tuanya secara optimal akan lebih sukses pencapaian toilet trainingnya daripada mereka yang tidak didampingi. Oleh karena itu penulis menetapkan ibu yang tidak bekerja sebagai kriteria inklusi dalam penelitian ini, mengingat bahwa keterbatasan dalam penelitian ini yang relative singkat jangka waktu pemantauan pre-postnya hanya satu minggu, dengan harapan bahwa ibu yang tidak bekerja dapat menjalankan sepenuhnya peran ibu sebagai orang tua, pendamping dan model dalam praktik toilet training selama proses intervensi berlangsung (Senjaputri, 2012).

Peran Ibu sebagai orang tua yaitu memantau memantau kesiapan fisik dan mental anak sampai membuat jadwal eliminasi BAK/BAB anak selama 24 jam. Peran Ibu sebagai pendamping dan model dalam praktik toilet training 
yaitu menunjukkan tempat yang benar untuk BAK/BAB yang benar, mendamping anak ketika menolak $\mathrm{BAk} / \mathrm{BAB}$ di toilet sehingga anak merasa aman dan nyaman, serta menjadi model bagi anak, bagaimana mengajarkan pada anak untuk mengkomunikasikan jika sensasi $\mathrm{BAK} / \mathrm{BAB}$ mulai dirasaka, mengajarkan duduk atau jongkok di toilet, mengajarkan cara memasang bantalan/alat pengaman potty training, mengajarkan cara membersihkan feses dan organ genital secara mandiri, mengajarkan melepas dan mengenakan celana secara mandiri (Senjaputri, 2012)

8) Usia, Menurut Wong (dalam Supartini,2009) kebanyakan anak akan mendapat kemampuan toilet training pada tahun kedua. Pada tahap ini juga, anak akan meniru perilaku orang lain di sekitarnya dan hal ini merupakan proses belajar bagi anak.

Usia dalam mencapai kemampuan toilet training yang optimal adalah antara 24-36 bulan. Hal ini di karenakan pada usia ini perkembangan bahasa anak baik secara verbal maupun non verbal sudah mampu mengkomunikasikan kebutuhannya dalam bereliminasi. Selain itu perkembangan motorik anak pada usia ini juga menunjukkan perkembangan yang lebih matang sehingga dapat mendukung dalam peningkatan kemampuan toilet training.

Penelitian sebelumnya James dalam Syafitri: jurnal kesehatan Undip) menyatakan bahwa : hal yang mempengaruhi kemampuan toilet training pada anak toddler dengan baik antara lain usia dan kesiapan anak. Di samping orang tua harus mempersiapkan dirinya sendiri, orang tua juga perlu memperhatikan tanda kesiapan anak yang meliputi kesiapan mental, fisik, psikologis. Penggunaan metode demonstrasi dapat di pakai untuk anak normal tetapi belum tentu dapat di pakai untuk anak berkebutuhan khusus (cacat fisik dan mental), sehingga perlu di cari metode yang tepat sehingga dapat di gunakan baik untuk anak normal maupun anak yang berkebutuhan khusus (cacat fisik dan mental).

Pada penenlitian ini, psikoedukasi dengan metode demonstrasi tidak hanya diberikan kepada responden ibu, intervensi dilanjutkan kepada responden anak dengan metode demonstrasi melalui video dan kartu bergambar selama 3 hari berturut-turut 
karena sasaran akhir dari keberhasilan pemberian psikoedukasi ini adalah anak yang akan melaksanakan tahapan ketrampilan toilet training. Dikatakan tahapan ketrampilan, karena pelaksanaan toilet training bagi anak tidak hanya sebatas aspek pengetahuan/kognisi saja tapi harus mampu melaksanakan ketrampilan tersebut.

Dari hasil analisis penelitian ini diperoleh hasil rerata yang semula 11,33 (pre) menigkat menjadi 14,80 (post) menunjukkkan secara kuantitatif bahwa kemampuan anak melaksanakan toilet training meningkat setelah di berikan intervensi. Secara kuantitatif perubahan ini tidak begitu besar, artinya 8 tahapan kemampuan anak dalam toilet training yang menjadi target psikoedukasi dalam penelitian ini bisa dikatakan tidak tuntas, dan hal ini menjadi keterbatasan penelitian. Adapun 8 tahapan kemampuan anak tersebut adalah :

1) Duduk/jongkok di toilet/wc tanpa rewel, menangis atau tiba-tiba pergi

2) Mengkomunikasikan secara verbal/non verbal sensasi $\mathrm{BAK} / \mathrm{BAB}$

3) Meminta ke toilet atau langsung pergi ke toilet

4) Melepas celana sendiri sebelum ke toilet

5) Membersihkan alat genital secara mandiri

6) Menyiram air seni/feses

7) Mengenakan celana secara mandiri

8) Mencuci tangan dengan sabun
Dari 8 tahapan tersebut ada 3 kemampuan yang belum tuntas selama proses intervensi berlangsung, terutama pada kelompok perlakuan, yaitu ; kemampuan no 5, 3 dan 1 dan. Hal ini bisa disebabkan karena :

a. Keterbatasan jeda waktu antara pre-post intervensi (selama 2 minggu)

b. Pada kemampuan 5 (membersihkan alat genital secara mandiri), berdasarkan hasil wawancara dengan ibu/responden, bahwa mereka masih belum memberi kepercayaan sepenuhnya kepada putraputrinya untuk membersihkan alat genital secara mandiri. Selain itu pada responden (anak) beberapa diantara mereka mempersepsikan feses adalah kotor, bau dan menjijikkan, sehingga masih ada yang menolak membersihkan secara mandiri

c. Pada kemampuan 1 dan 3 (Duduk/jongkok di toilet/wc tanpa rewel, menangis atau tiba-tiba pergi dan meminta ke toilet atau langsung pergi ke toilet ) berdasarkan hasil wawancara dengan responden (ibu dan anak) masih mempunyai kehawatiran takut jatuh atau terpeleset.

\section{SIMPULAN DAN SARAN}

\section{Simpulan}

a. Psikoedukasi tentang toilet training dengan demonstrasi video dan kartu bergambar cukup efektif sebagai metode pembelajaran dalam merubah perilaku 
orang tua khususnya ibu pada aspek pengetahuan dan psikomotor. Hal ini karena demonstrasi terutama audio visual (video dan kartu bergambar) dapat menstimulasi kognisi seseorang yang asalnya tidak tahu menjadi tahu atau lebih memahami.

b. Psikoedukasi tentang toilet training dengan demonstrsi video dan kartu bergambar juga cukup efektif dalam menstimulasi meningkatkan kemampuan anak yang asalnya tidak bisa sampai mampu melaksanakannya.

\section{Saran}

a. Bagi Pendidik, Orang Tua dan Pengasuh baik di rumah \& Tempat Penitipan Anak 1) Diharapkan kepada pihak masyarakat dan tempat penitipan anak agar dapat menerapkan demonstrasi media video dan kartu bergambar untuk meningkatkan kemampuan toilet training pada anak toddler.

2) Memberikan perhatian, dampingan dan support bagi anak-anak yang sedang melaksanakan toilet training

3) Melaksanakan tahapan/prosedur toilet training dengan cara yang baik dan benar

b. Bagi Institusi Pendidikan

Bisa memanfatkan hasil penelitian ini sebagai sumber informasi dalam pengembangan ilmu pengetahuan khususnya tentang manfaat psikoedukasi melalui demonstrasi video dan kartu bergambar bagi anak toddler yang belum berhasil atau sedang diajarkan toilet training.

c. Bagi Peneliti Selanjutnya

1) Untuk pelaksanaan intervensi (jeda pre-post) sebaiknya ada jarak waktu yang cukup/tidak terlalu singkat sehingga 8 tahap ketrampilan toilet training dapat tercapai dengan tuntas

2) Materi video dan kartu bergambar sebaiknya disesuaikan dengan sarana prasarana responden (misalnya gambar wc jongkok, dsb.)

3) Perlu dikembangkan program toilet training sebagai persyaratan masuk sekolah Taman Kanak-Kanak.

4) Perlu dikembangkan prosedur toilet training untuk anak-anak cacat atau berkebutuhan khusus.

\section{DAFTAR PUSTAKA}

Alwisol. 2004. Psikologi Kepribadian. Malang: Universitas Muhammadyah malang.

Burn, N, Grove, S. K. 2005. Thepractic of nursing research: conduct,critique, and utilization. Missouri : Elsevier Saunders.

Crain, W. (2007. Teori perkembangan: Konsep dan aplikasi (Edisi ketiga ,terjemahanYudiSantoso). Yogjakarta: Pustaka Pelajar.

Dahlan, M. S. 2009. Statistik untuk Kedokteran dan Kesehatan.Jakarta: Salemba Medika.

Gilbert, J. 2003. Seri panduan praktis keluarga latihan toilet. jakarta: Erlangga.

Hall, C. S., Lindzey, G. (2012). Teori-teori sifat dan behavioristik. Yogyakarta: 
Kanisius.

Hidayat, A. A. A.(2007). Riset keperawatan dan teknik penulisan ilmiah. Jakarta: Salemba Medika.

Hidayat, A. 2009. Pengantar Keperawatan Anak 1. Jakarta: Salemba Medika.

Keen, D, B, K.L,Cruskelly,M. 2007. Toilet training for children with autism: the effects of video modeling, hlm 291-303. Diperoleh tanggal 1 Desember 2012 dari: http://www98.griffith.edu.au/dspa/ce/ bitstream/handle/10072/16968/ 47013_1.pdf?sequence $=1$.

Khusniah. 2012. Peningkatan kemampuan bercerita melalui gambar seri pada anak kelompok A di TK Surya Harapan Candi Sidoarjo. Skripsi. Diperoleh tanggal 31 Mei 2013 darijournal.unesa.ac.id/article/2493/ 19/article.pdf

Luxner, K. L., Jaffe, M. S. 2005. Pediatric Nursing Care Plants, 3rd Edition. USA: Thomson Learning.

Margareta, S. E. P. M. 2012. Efektifitas video self modelling terhadap kemampuan menggosok gigi pada anak dengan autisme spectrum disorders di Karesidenan

Banyumas. Tesis. Diperoleh tanggal 31 Mei 2013 darilontar.ui.ac.id/file?file $=$ digital $/ 23$ 04751...\%20Efektivitas\%20video. Pdf

Notoatmodjo, S. 2003. Pendidikan dan perilaku kesehatan. Jakarta: PT.Rineka Cipta.

Salimah. 2011. Dampak penerapan bermain dengan media gambar seri dalam mengembangkan keterampilan berbicara dan penguasaan kosa kata anak usia dini. Diperoleh tanggal 9 Februari 2013 dari jurnal.upi.edu/file/18-salimah.pdf.
Wong,L.D.,Eaton,H.M.,Wilson,D., Winkelst ein, L. M., dan Schwartz,P. (ed 6). 2008. Buku ajar keperawatan pediatric (A.Hartono,S.kurnianingsih \&Setiawan, Terj.). Jakarta: EGC. (Naskah asli dipublikasikan tahun 2001).

Yusuf, S. 2011. Teori kepribadian. Bandung : Remaja Rosdakarya.

Zaviera, F. 2008. Mengenali dan memahami tumbuh kembang anak. Jakarta: Katahati. 